\title{
A study on HPV mRNA test and colposcopy in HIV positive women for early detection of cervical intraepithelial lesions
}

\author{
Kavita N. Singh*, Sheetal Achale, Vineeta Ghanghoriya
}

Department of Obstetrics and Gynecology, Netaji Subhash Chandra Bose Medical College, Jabalpur, Madhya Pradesh, India

Received: 03 April 2017

Revised: 13 April 2017

Accepted: 03 May 2017

*Correspondence:

Dr. Kavita N. Singh,

E-mail: drkavitasingh@rediffmail.com

Copyright: ( ) the author(s), publisher and licensee Medip Academy. This is an open-access article distributed under the terms of the Creative Commons Attribution Non-Commercial License, which permits unrestricted non-commercial use, distribution, and reproduction in any medium, provided the original work is properly cited.

\begin{abstract}
Background: Sexually transmitted infections (STIs) have a profound impact on sexual and reproductive health worldwide. At any point of time, globally more than 290 million women suffer from HPV infection, one of the most common STIs. There are only few studies from India reported regarding the prevalence of HPV and cervical abnormalities among HIV-positive women. This study was carried out to estimate the prevalence of HPV and other genital tract infection in HIV positive women and correlate HPV mRNA test and colposcopic findings with cytohistopathology in HIV positive women who are not on antiretroviral therapy (ART). Secondary objective was to benefit HIV positive women by making them aware about the importance of screening, early detection and treatment of various lower genital tract infections, CIN and cancer cervix.

Methods: cross sectional observational study was conducted in department of Obstetrics and Gynecology, NSCB medical college Jabalpur (M.P.) from March 2015 to August 2016 on 70 HIV positive women in whom anti-retroviral therapy was not started. This study was approved by institutional ethical committee. The data was recorded in predesign coded case report form and statistical analysis was performed using the STATA 12.1.

Results: In the present study, prevalence of lower genital tract infections in HIV positive women not on ART was $30.0 \%$ and the prevalence of high risk HPV was $5.9 \%$.

Conclusions: The study concludes that diagnostic efficacy of HPV mRNA test has similar diagnostic value as that of histopathology report.
\end{abstract}

Keywords: CIN, Colposcopy, HIV, High risk HPV, HPV mRNA

\section{INTRODUCTION}

Sexually transmitted infections (STIs) have a profound impact on sexual and reproductive health worldwide. According to WHO factsheet 2016 more than 1 million STIs are acquired every day. Each year, there are estimated 357 million new infections with 1 of 4 STIs: chlamydia (131 million), gonorrhoea (78 million), syphilis (5.6 million) and trichomoniasis (143 million).
More than 500 million people are living with genital HSV (Herpes Simplex Virus) infection. At any point in time, more than 290 million women suffer from HPV infection, one of the most common STIs. ${ }^{1}$ STIs can have serious consequences beyond the immediate impact of the infection itself.

India has the third largest number of people living with HIV/AIDS (acquired immunodeficiency syndrome) and 
accounts for nearly 1/4th of the global cervical cancer deaths. Of the 2.09 million people living with HIV/AIDS in India, 39 per cent are women., ${ }^{2,3}$ There are only few studies from the country regarding the prevalence and types of HPV and cervical abnormalities among HIVpositive women. A hospital based study from the eastern part of India observed a prevalence of oncogenic HPV among HIV-positive women to be $46.2 \%$ whereas a study from northern India showed a prevalence of high-risk $\mathrm{HPV}$ in $20 \% .4,5$

\section{Justification}

HIV positive women are at higher risk of developing reproductive tract infections as compared to HIV negative women. Large observational studies involving HIV positive women have demonstrated a strong and consistent association between confection with HIV, HPV and CIN. It is therefore important for the clinicians to screen women who are HIV positive for reproductive tract infections and CIN. Previously similar study in the department revealed high rate of regression of HPV infection in HIV positive women who were on ART. ${ }^{6}$

The present study is planned to know the prevalence of HPV and other lower genital tract infection in HIV positive women who are not on ART and also correlating colposcopic findings and HPV mRNA test results with cyto-histopathology reports in the study group.

\section{METHODS}

A cross sectional observational study was conducted in Department of Obstetrics and Gynaecology, NSCB medical college Jabalpur (MP), India from March 2015 to $31^{\text {st }}$ August 2016 on $70 \mathrm{HIV}$ positive women not yet started anti-retroviral therapy. Ethical approval was taken from institutional ethical committee.

All women above 18 years, who are sexually active and HIV positive not on ART irrespective of their pregnancy status were included in the study group. HIV positive women who were taking anti-retroviral therapy (ART), women with bleeding per vaginum and women with visible growth on Cervix were excluded from the study

HIV positive women were counselled for gynaecological examination and testing in the department of gynaecology. Total 96 HIV positive women were counselled and out of these 70 women gave consent for examination and testing. They were explained the procedure and informed consent was taken. The patient was taken on the colposcopy examination chair. Colposcopic examination (Karl Kaps Germany) of the perianal region and vulva was done. A self-retaining Cusco's speculum was applied. With the help of two cytobrushes, sample from ectocervix and endocervix was taken, Pap smear fixed with $95 \%$ ethanol and slides were sent to Pathology Department for examination and at the same time sample was placed in the HPV mRNA vial and was sent by courier to Cure Health Diagnostics Pvt Ltd. within 24 hours of collection (free samples were issued for research work). Cervix was cleaned with saline swab. Ectocervix and vagina was examined under magnification and green filter. Freshly prepared 5\% glacial acetic acid solution was applied on the ectocervix $(5 \mathrm{ml}$ of glacial acetic acid mixed with $95 \mathrm{ml}$ of distilled water). As per IFCPC 2011 classification normal and abnormal findings were noted and scoring was done as per modified RCI index. ${ }^{7,8}$ The cervix was divided into four quadrants by an imaginary line passing through the centre from 6'o clock to12'o clock position and from 3'o clock to 9'o clock position and Colposcopic examination of each quadrant was done in a clockwise direction starting from right upper quadrant and findings documented as equation by simplified RCI scoring method. ${ }^{9}$ If the score was more than 2, then biopsy was taken and send for histopathology reporting in Department of Pathology, NSCB medical college, Jabalpur (MP). At later date pap test, HPV mRNA, Colposcopy findings and histopathology reports were noted and analysed.

Basic demographic characteristics clinical presentation and laboratory findings were recorded in predesigned case report from all studied cases. Numerically coded data entered in MS excel 2007 worksheet and logical validation and editing was done before analysis. Categorical variables were summarized as frequency distribution and mean $( \pm \mathrm{SD})$ was analysed using chi square or fisher's exact test as appropriate. Sensitivity, specificity, positive and negative predictive values with 95\% confidence interval was also calculated for diagnostics. Statistical analysis was performed using STATA 12.1 .

\section{RESULTS}

The background characteristics of studied group revealed $51.4 \%$ women were between $31-39$ years of age. $61.4 \%$ by occupation were belonging to rural area. $92.9 \%$ of women were Hindu by religion. $65.7 \%$ of women not educated.by occupation $65.7 \%$ of women were housewife. $37.1 \%$ women had marital life of less than 5 years and $34.3 \%$ had marital between 5-10 years. $30 \%$ women were para 2 and $28.6 \%$ were para 1 (Table 1). Majority $58.6 \%$ cases, presented with complaint of white discharge followed by $14.3 \%$ with itching, $11.4 \%$ with burning micturition, $5.3 \%$ with abdominal pain, $8.6 \%$ with irregular bleeding per vaginum, $4.3 \%$ with postcoital bleeding and $2.9 \%$ with other complaints. A case who was diagnosed as CIN 2 presented with complaint of itching over private parts and a case diagnosed as CIN 3 presented with complaint of irregular bleeding per vaginum (Figure 1).

Prevalence of lower genital infections in HIV positive women in the present study was $30 \%(n=21)$. Out of which $14.2 \%$ cases had candidiasis, $14.2 \%$ cases had trichomoniasis, $5.9 \%$ with high risk HPV infection, $4.7 \%$ 
cases with vulval condyloma and $61 \%$ with cervicitis due to other causes (Figure 2).

Table 1: Demographic characteristics of the study group.

\begin{tabular}{|lll|}
\hline Variable & Frequency & $\%$ \\
\hline Age (Years) & & \\
\hline $20-30$ & 25 & 35.7 \\
\hline $31-39$ & 36 & 51.4 \\
\hline $40-49$ & 06 & 8.6 \\
\hline$>60$ & 03 & 4.3 \\
\hline Locality & & \\
\hline Rural & 43 & 61.4 \\
\hline Urban & 27 & 38.6 \\
\hline Religion & & \\
\hline Hindu & 65 & 92.9 \\
\hline Muslim & 05 & 7.1 \\
\hline Education & & \\
\hline Illiterate & 46 & 65.7 \\
\hline Primary & 11 & 15.7 \\
\hline Middle & 08 & 11.4 \\
\hline Secondary & 04 & 5.7 \\
\hline Graduate & 02 & 1.4 \\
\hline Occupation & & \\
\hline Daily wage worker & 20 & 29.6 \\
\hline Farmer & 08 & 2.9 \\
\hline Service & 08 & 2.9 \\
\hline Housewife & 46 & 65.7 \\
\hline Duration of marriage & & 37.1 \\
\hline < 5 years & 26 & 30.3 \\
\hline $5-10$ & 24 & 24.3 \\
\hline $11-20$ & 12 & 05 \\
\hline $21-30$ & 03 & \\
\hline$>31$ & 20 & \\
\hline Parity & 21 & \\
\hline 1 & 08 & \\
\hline 2 & & \\
\hline 3 & & \\
\hline$>4$ & & \\
\hline & & \\
\hline
\end{tabular}

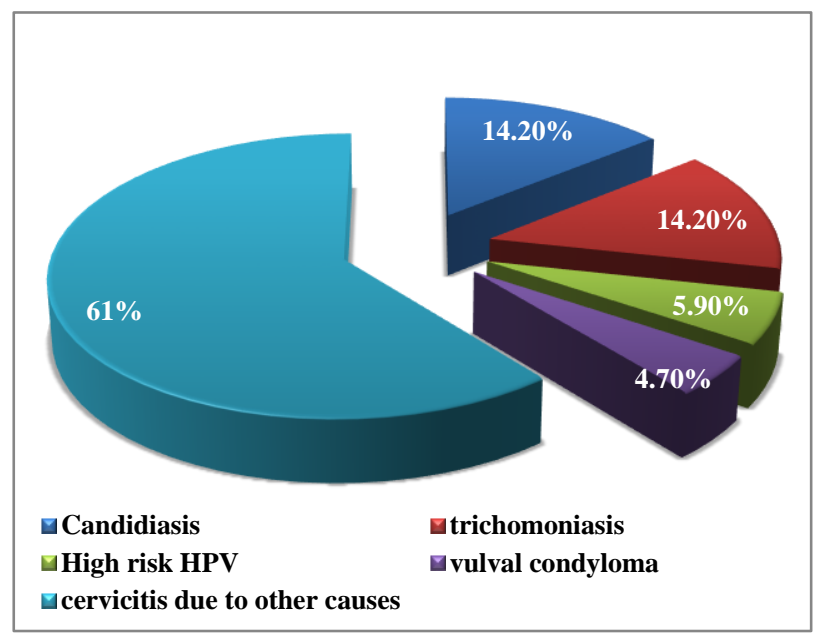

Figure 1: Prevalence of lower genital tract infections.
Majority $41.4 \%$ cases had CD4 count $>500$ cells/cumm, $52.9 \%$ cases had 200-499 cells/cumm and remaining $5.7 \%$ cases had $<200$ cells/cumm. There were 2 case with major colposcopic findings (CIN 2, 3) who had CD4 count was $<200$ cells/cumm.

On cytology $91.4 \%(n=64)$ cases revealed negative for intraepithelial lesion (NILM), 7.1\% $(n=5)$ cases revealed ASCUS and $1.5 \%(n=1)$ revealed LSIL. Out of 5 ASCUS one case revealed major colposcopic findings and 4 cases revealed minor colposcopic findings. One case reported LSIL revealed major colposcopic findings. This was found statistically significant $(\mathrm{p}=0.002)$.

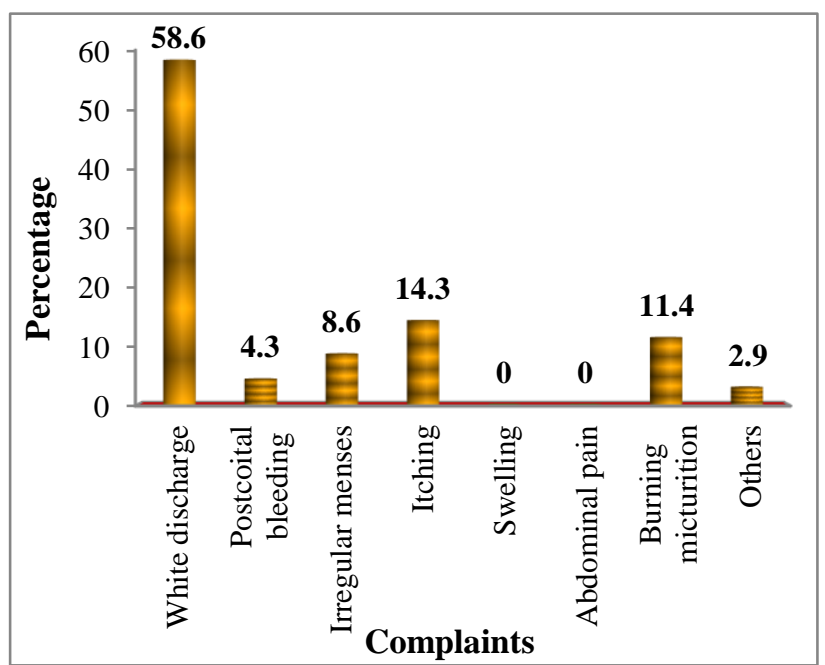

Figure 2: Distribution of cases according to presenting complaints.

In two cases with positive HPV mRNA testcolposcopy also detects the major colposcopic findings and was statistically significant. $(\mathrm{p}=0.002)$ and the same two cases histopathology confirmed the CIN2 and CIN3.This finding was statistically significant. ( $p$ value $=0.002$ )

Sensitivity of colposcopy against HPV mRNA test is $100 \%$ (95\% confidence interval $15.8 \%-100 \%$ )

Specificity of colposcopy against HPV mRNA test is $59.4 \%$ (95\% confidence interval $40.6-76.3 \%$ ). Positive predictive value of colposcopy against HPV mRNA test is $13.3 \%$ (95\% confidence interval $1.7-4.5 \%$ )

Negative predictive value of colposcopy against HPV mRNA test is $100 \%$ (95\% confidence interval 82.8 99.9\%). Specificity and PPV of colposcopy was less in our study due to the reason that it detects the minor findings also. Sensitivity of cytology against HPVmRNA test is $50 \%(95 \%$ CI $1.3 \%-98.7 \%)$. Specificity of cytology against HPV mRNA test is $90.6 \%$ (95\% CI 7598\%). Positive predictive value of cytology against HPV mRNA test is $25.0 \%$ (95\% CI $0.6-80.6 \%)$. 
Negative predictive value of cytology against HPV mRNA test is $96.7 \%$ (95\% CI 82.8-99.9\%). Sensitivity of HPV mRNA test against histopathology is $100 \%(95 \%$ confidence interval $15.8 \%-100 \%)$. Specificity of HPV mRNA test against histopathology is $100 \% \quad(95 \%$ confidence interval $89.1-100 \%$ ). Positive predictive value of HPV mRNA test against histopathology is $100 \%$ (95\% confidence interval $15.8 \%-100 \%)$. Negative predictive valueof HPV mRNA test against histopathology is $100 \%$ (95\% confidence interval 89.1-100\%).

Table 2: Association of colposcopic findings with CD4 cell count.

\begin{tabular}{|c|c|c|c|c|c|}
\hline & Normal study (n=49) & $\begin{array}{l}\text { Minor colposcopic findings } \\
(\mathrm{n}=19)\end{array}$ & $\begin{array}{l}\text { Major colposcopic } \\
\text { findings }(\mathrm{n}=2)\end{array}$ & $X^{2}$ & P value \\
\hline $\mathrm{CD}_{4}$ cell count & & & & 36.90 & 0.002 \\
\hline$<200$ & $1(25 \%)$ & $1(25 \%)$ & $2(50 \%)$ & & \\
\hline $200-500$ & $24(64.9 \%)$ & $13(35.1 \%)$ & 0 & & \\
\hline$>500$ & $24(82.8 \%)$ & $05(17.2 \%)$ & 0 & & \\
\hline
\end{tabular}

Table 3: Association of HPV mRNA test with colposcopy, cytology and histopathology.

\begin{tabular}{|c|c|c|c|c|}
\hline & $\begin{array}{l}\text { Positive } \\
(\mathrm{n}=2)\end{array}$ & $\begin{array}{l}\text { Negative } \\
(\mathrm{n}=32)\end{array}$ & $\mathrm{X}^{2}$ & $\begin{array}{l}P \\
\text { value }\end{array}$ \\
\hline Colposcopy & & & 34.0 & 0.002 \\
\hline Normal & 0 & $19(59.3 \%)$ & & \\
\hline Minor & 0 & $13(40.6 \%)$ & & \\
\hline Major & $2(100 \%)$ & 00 & & \\
\hline \multicolumn{5}{|l|}{ Cytology } \\
\hline NILM & 0 & $29(90.6 \%)$ & \multirow{3}{*}{16.54} & \multirow{3}{*}{0.064} \\
\hline ASCUS & $01(50 \%)$ & $03(9.4 \%)$ & & \\
\hline LSIL & $01(50 \%)$ & 00 & & \\
\hline \multicolumn{5}{|c|}{ Histopathology } \\
\hline Positive & $02(100 \%)$ & 0 & \multirow{2}{*}{34} & \multirow{2}{*}{0.002} \\
\hline Negative & 0 & $32(100 \%)$ & & \\
\hline
\end{tabular}

\section{DISCUSSION}

\section{Distribution of cases according to age}

In the present study about $51 \%$ cases were from age group of 31-39 years. The two major colposcopic findings with HPV mRNA positive both were from the age group of 31-39 years. Out of 19cases with minor colposcopic changes, 12 cases $(27.7 \%)$ were in the 31-39 years. A study by V Goel et al (2011), The median age was 30 years (range 21-43 years) with most of them 14 , (35\%) being in the age group 26-29 years followed by 13 (32\%) between 30 and 35 years. ${ }^{10}$ Similar study by Sarkar et al (2011), risk becomes higher when age was more than $30 .{ }^{4}$ According to present study lower genital tract infections were more prevalent in age group between 31-39 years. Probably this was related with declining body immunity as seen in more advanced HIV infected cases.

\section{Association of colposcopic findings with cytology}

Findings suggested in this study that $91 \%$ cases revealed NILM, $7.1 \%$ revealed ASCUS and $1.5 \%$ revealed LSIL.
1 case with major colposcopic finding revealed LSIL and 1 case revealed ASCUS on pap smear reporting. This finding was found statistically significant $(\mathrm{p}=0.002)$.

\section{Association of colposcopic findings with CD4 count}

About $41 \%$ cases had CD4 >500 cells/cumm, 53\% cases had CD4 200-499 cells/cumm and remaining 5.7\% cases had CD4 cells $<200$ cells/cumm. There were 2 case with major colposcopic changes with positive HPV mRNA test had CD4 count was $<200$ cells/cumm. This finding was found to be statistically significant (Table 2).

In a study by Badkur et al, $4 \%$ of studied population had CD4 count of $<200$ cells $/ \mathrm{mm}, 36 \%$ had CD4 count of 200499cells/cumm and $60 \%$ had CD4 cells $>500$ cells/cumm and was statistically significant. ${ }^{6}$ Similar results were reported by Harrish TG et al and in a study by $\mathrm{S}$ Rugpao et al, but these trends were not significant. ${ }^{11,12}$

\section{Association of HPVmRNA testing with colposcopy}

In the present study, HPV mRNA testing was done in 34 cases, of which $5.9 \%(n=2)$ cases were positive for high risk HPV infections whereas 32 out of 34 (94.1\%) test reported negative for HPV mRNA test.

The test was not performed in 36 patients due to various logistic reasons (missing samples, leaked samples during transportation etc.).

Two cases with major colposcopic findings revealed positive HPV mRNA test and which was further confirmed by histopathology. This was statistically significant. $(\mathrm{p}=0.021)$ (Table 3$)$. A prospective cohort study done by Sveinung Wergel and Sørbye et al, HPV mRNA positivity was $7.1 \%$ in women aged $25-33$ years and $2.1 \%$ in women aged 34-69 years which was much lower than those reported from studies using HPV DNA tests. ${ }^{13}$ 


\section{Association of HPV mRNA test with cytology}

There were two patients with positive HPV mRNA test and in 1 case revealed ASCUS and in 1 case pap smear revealed LSIL. This finding was statistically significant (Table 3).

\section{Association of HPV mRNA test with histopathology}

There were two patients with positive HPV mRNA test i.e. overexpression of E6/E7 and in both cases histopathology detects the CIN2 and CIN3. This finding was statistically significant (Table 3).

\section{CONCLUSION}

In the present study, prevalence of lower genital tract infections in HIV positive women who were not on ART was $30.0 \%$. In the present study, prevalence of high risk HPV was $5.9 \%$.

Present study concludes that diagnostic efficacy of HPV mRNA test is similar to that of histopathology report. All HIV positive women not on ART should be made aware for importance of screening, early detection and management of lower genital tract infections, HPV infection CIN and cancer cervix.

\section{ACKNOWLEDGMENTS}

Authors would like to thanks Dr. Prof. R. Chauhan, (MS; FICMCH), Professor and Head, Department of Obstetrics and Gynecology, Netaji Subhash Chandra Bose Medical College Jabalpur, MP, India for her kind support. Mr. M P Singh, ICMR Jabalpur for statistical analysis, Dr Dinesh Gupta, laboratory director, cure health diagnostic centre, Delhi and Dr. Namita Parashar senior medical officer ART centre, Jabalpur for their constant support.

Funding: No funding sources Conflict of interest: None declared

Ethical approval: The study was approved by the Institutional Ethics Committee

\section{REFERENCES}

1. Sanjose S, Diaz M, Castellsague X, Clifford G, Bruni L, Munoz N, et al. Worldwide prevalence and genotype distribution of cervical human papillomavirus DNA in women with normal cytology: a meta-analysis. Lancet Infect Dis. 2007;7(7):453-9.

2. New Delhi: Department of AIDS Control, National AIDS Control Organization, Ministry of Health and
Family Welfare, Government of India; 2014. Annual Report; 2013-14.

3. Bruni L, Barrionuevo-Rosas L, Albero G, Aldea M, Serrano B, Valencia S, et al. ICO Information Centre on HPV and Cancer (HPV Information Centre). Human papillomavirus and related diseases in India Summary report; 2015-12-23.

4. Sarkar K, Pal R, Bal B, Saha B, Bhattacharya S, Sengupta S, et al. Oncogenic HPV among HIV infected female population in West Bengal, India. BMC Infect Dis. 2011;11:72.

5. Aggarwal R, Sachdeva RK, Naru J, Suri V, Sharma A, Nijhawan R. HPV genotyping in north Indian women infected with HIV. Int J Gynecol Pathol. 2012;31:475-81.

6. Badkur P, Singh KN, Ghanghoriya V. Colposcopic study of lower genital tract infections in HIV positive women on antiretroviral therapy. J Obstetgynecol India. 2016;66:471-7.

7. Sellors JW, Sankaranarayanan R. Colposcopy and treatment of cervical intraepithelial neoplasia. Geneva: WHO; 2003;2003 Sep 20.

8. Bornstein J, Bentley J, Bösze P, Girardi F, Haefner $\mathrm{H}$, Menton M, et al. 2011 colposcopic terminology of the International Federation for Cervical Pathology and Colposcopy. Obst Gynecol. 2012;120(1):166-72.

9. Singh KN, Chakma T, Verma S. Colposcopic assessment of the cervix using the simplified Reid"s Colposcopic Index method. Current Science. 2009; 96(3):386-91.

10. Goel V, Bhalla P, Sharma A, Mala YM. Lower genital tract infections in HIV-seropositive women in India.Indian Journal of Sexually Transmitted Diseases and AIDS. 2011;32(2):103.

11. Harris TG, Burk RD, Palefsky JM. Incidence of cervical squamous intraepithelial lesions associated with HIV serostatus, CD4 cell counts, and human papillomavirus test results. JAMA. 2005;293(12):1471-6.

12. Rugpao S, Srisomboon J, Chaiyarassamee O, Nelson KE, Nagachinta $T$, Suriyanon $V$, et al. Gynaecological conditions associated with HIV infection in women who are partners of HIV-positive Thai blood donors. Internat J STD AIDS. 19981;9(11):677-82.

13. Sørbye SW, Fismen S, Gutteberg TJ, Mortensen ES, Skjeldestad FE. Primary cervical cancer screening with an HPV mRNA test: a prospective cohort study. BMJ open. 2016;6(8):e011981.

Cite this article as: Singh KN, Achale $S$, Ghanghoriya V. A study on HPV mRNA test and colposcopy in HIV positive women for early detection of cervical intraepithelial lesions. Int J Reprod Contracept Obstet Gynecol 2017;6:2522-6. 